\title{
MOBILNI KOMUNIKACIONI SISTEMI I APLIKACIJE OD ZNAČAJA ZA INTEGRISANO UPRAVLJANJE KATASTROFAMA
}

\author{
Maja Svrdlin \\ Naučno-stručno društvo za upravljanje rizicima u \\ vanrednim situacijama, Beograd \\ Vladimir M. Cvetković \\ Univerzitet u Beogradu, Fakultet bezbednosti
}

Savremeno upravljanje u katastrofama uslovljava iznalaženje optiOmalnih rešenja u pogledu mobilnih komunikacionih sistema i aplikacija koje se mogu koristiti za unapređivanje efikasnosti sistema zaštite i spasavanja. Multidisciplinarnost i suštinska komplikovanost procesa upravljanja rizicima od katastrofa uslovljava korišćenje različitih logističkih alata i opreme. U tom smislu, informaciono-komunikacione tehnologije igraju značajnu ulogu jer one na svojevrstan način podižu nivo sposobnosti ljudi za brzo odlučivanje i smanjuju mogućnosti nastanka različitih grešaka.

$U$ radu se opisuju karakteristike i načini korišćenja najpoznatiji mobilnih aplikacija koje se širom sveta koriste u integrisanom upravljanju katastrofama sa ciljem pružanja pomoći i podrške pripadnicima interventno-spasilačkih jedinica i drugim ugroženim građanima. Pored toga, sveobuhvatno se sagledavaju postojeći i očekivani izazovi i problemi u normalnom funkcionisanju mobilnih komunikacionih sistema i aplikacija u uslovima katastrofa.

Ključne reči: bezbednost, mobilni telefoni, mobilni sistemi, aplikacije, upravljanje, katastrofe

Katastrofe izazvane prirodnim ili tehničko-tehnološkim opasnostima predstavljaju situacije koje nadmašuju sposobnosti lokalnih, regionalnih i nacionalnih entiteta uslovljavajući traženje pomoći od međunarodnih organizacija i eksperata (Moe et al., 2007:787). Milijarde ljudi u više od sto država sveta periodično je izloženo barem jednoj katastrofi izazvanoj prirodnom opasnošću (Moe et al., 2007), a do sada ih je identifikovano oko 30 vrsta (Deshmukh et al., 2008). Svaka katastrofa ima razarajuće posledice po ljudske živote, ekonomiju, društvenu stabilnost i životnu sredinu. Kako se njihova učestalost i obim na planetarnom nivou svake godine sve više povećava (Warren, 2010), raste i potreba da se umanje i rizici (Cvetkovic, 2019; Cvetković et al., 2019; Cvetković et al, 2018; 2018a), razvije neophodna otpornost zajednica, te da se one što bolje pripreme, a kako bi 
se uspešno na iste odgovorilo i što brže i efikasnije nakon katastrofe ugroženo područje oporavilo. U skladu sa tim, upravljanje katastrofama uz pomoć informaciono-komunikacionih tehnologija i konkretno mobilnih uređaja odnosno mobilnih aplikacija, igra vitalnu ulogu u sve četiri faze ovog ciklusa, prevenciji, pripremi, odgovoru i oporavku. Upravljanje katastrofama se javlja kao suštinski i neraskidiv dinamičan proces, koji uključuje sve klasične funkcije menadžmenta poput planiranja, organizovanja, kontrolisanja i vođenja, pri čemu veći broj različitih interventno-spasilačkih službi radi zajedno kako bi se sprečile i ublažile posledice katastrofa, odnosno kako bi se unapredile ne samo preventivne nego i odgovarajuće represivne mere odgovora, a nakon toga i oporavka (Carter 2008, 19).

Multidisciplinarnost i suštinska komplikovanost procesa upravljanja rizicima od katastrofa (Aleksandrina et al., 2019; Ocal, 2019) uslovljava korišćenje različitih logističkih alata i opreme. $U$ tom smislu, informaciono-komunikacione tehnologije igraju značajnu ulogu jer one na svojevrstan način podižu nivo sposobnosti ljudi za brzo odlučivanje i smanjuju mogućnosti nastanka različitih grešaka. Kada se spomenu informaciono-komunikacione tehnologije, prevashodno se misli na sisteme za rano upozoravanje, geografsko-informacione sisteme, baze podataka o katastrofama, udaljene sisteme senzora, satelitske komunikacije, radio, Internet, televiziju, socijalne mreže, te mobilne uređaje. Od svih pomenutih, a sa rapidnim razvojem operativnih sistema i broja korisnika u poslednje dve decenije, mobilne tehnologije su postale nezaobilazan instrument vitalne podrške menadžmentu u upravljanja katastrofama na više načina, kroz monitoring, komunikaciju, širenje upozorenja, pružanje informacija o evakuaciji, spasavanju i slično. Klasa naprednih mobilnih uređaja kao što su pametni telefoni, uz svojstva koja poseduju poput višestruko ugrađenih senzora, ili sposobnosti razmene različite vrste i velikog obima mrežnih podataka, otvaraju prostor i za efikasniju komunikaciju i kvalitetnije donošenje odluka, a sve to uz manje utrošenih materijalnih resursa, kao i vremena koje u katastrofama uvek manjka, ma koliko ga bilo. U proteklim decenijama, centralizovano upravljanje katastrofama korišćenjem vojničke hijerarhije odlučivanja i krutih struktura u sve četiri faze ovog ciklusa, a pogotovo tokom samog odgovora, pokazale su se nedovoljnim za uspešno vođenje čitavog procesa, naročito zbog sve većeg obima katastrofa i nužnošću za agilnim, a istovremeno koordinisanim i planski orijentisanim akcijama (Palmer et al., 2012). Sve očiglednija potreba za drugačijim, fleksibilnijim pristupom, gde će ljudi i tehnologija biti jedan od primarnih i kritičnih aktera pre, tokom i posle katastrofa podudara se sa razvojem iformaciono-komunikacionih tehnologija, mobilnih uređaja i nešto kasnije, mobilnih aplikacija projektovanih za pomoć u konkretnim izazovima koje prate katastrofu.

Autori u radu sagledavaju mogućnosti i ograničenja upotrebe informaciono-komunikacione tehnologije, detaljno razmatraju korišćenje mobilnih telefona i drugih mobilnih aplikacija, i prikazuju prepreke koje prate njihovo osmišljavanje, implementaciju i primenu u praksi.

\section{Informaciono-komunikacione tehnologije i integrisano upravljanje katastrofama}

lako nije uvek moguće u potpunosti eliminisati rizik, iskustva i praksa su pokazale da posledice katastrofa, kao i nivo ugroženosti mogu biti ublaženi ako se ljudi za njih proaktivno pripreme (Kumiko \& Shaw, 2019; Xuesong \& Kapucu, 2019). U tom smislu, informacio- 
no-komunikacione tehnologije potencijalno igraju veoma značajnu ulogu, jer mogu pomoći da se reše upravo složeni problemi koristeći socio-tehnološki pristup. Informaciono-komunikacione tehnologije obuhvataju kako tradicionalne (radio, televiziju), tako i moderne medije, poput Interneta, senzora, satelitskog radija i mobilne tehnologije (Hassan, 2015). lako se njihova primena obično vezuje za faze odgovora i oporavka, nove tehnologije nastale početkom devedesetih godina prošlog veka povećavaju mogućnosti primene i u fazi prevencije i ublažavanja katastrofa (Yodmani \& Hollister, 2001). Raznovrstan je niz dostupnih informaciono-komunikacionih tehnologija koje mogu unaprediti proces upravljanja rizicima i smanjenja rizika od katastrofa (UN-APCICT/ESCAP, 2016:36). Među glavnim alatima koji se spominju u upravljanju rizicima od katastrofa, značajni su sledeći (Fatma, 2012:476): 1. sistemi za rano upozoravanje i simulacioni modeli: omogućavaju dobijanje i deljenje informacija o potencijalnim efektima katastrofa, riziku i broju ugroženih ljudi kako bi se na vreme izvršila evakuacija i umanjile posledice, dok se simulacioni modeli koriste kao instrumenti tokom pripreme za donošenje odluka i planiranje; 2. baze podataka o katastrofama dostupne na internet adresama: kompjuterski sistemi podataka o ugroženim i ranjivim zajednicama i objektima, koji služe kao alati za identifikovanje rizika i formiranje strategije odgovora na katastrofu; 3. satelitske komunikacije: pomažu kod realizacije operacija potrage i spasavanja ugroženih, koristeći se globalnim sistemom za pozicioniranje i fotografijama iz vazduha kako bi se odredile tačne koordinate lokacija na koje je potrebno dostaviti pomoć, ali takođe i pratiti aktivnosti operativnih snaga na terenu, situacije na ugroženim površinama, te podržati sisteme za rano upozoravanje brzim i tačnim informacijama; 4. udaljeni senzorni sistemi: koristeći se optičkim i radarskim satelitskim sistemima, ove tehnologije pomažu da se prilikom prostornog planiranja na površinama ugroženim od katastrofa lakše i preciznije odrede mogući rizici po infrastrukturu i ljude; 5. geografski-informacioni sistemi (GIS): GIS svemirska tehnologija omogućava da se bolje pripremimo za katastrofe kroz analizu situacije ugroženog područja, procenu i mapiranje rizika, nadziranje i monitoring rizičnih površina; 6. sistemi za pomoć u odlučivanju: alati koji pomažu pri ranom upozoravanju, ublažavanju i pripremanju odgovora; 7 . internet sajtovi, elektronska pošta i socijalni medij: tehnologije koje omogućavaju podizanje svesti stanovništva, iskazivanje i razmenu mišljenja o rizicima od katastrofa, promovisanje saradnje, upozoravanje zajednice na dolazeću katastro$\mathrm{fu}$, krizno komuniciranje sa različitim javnostima i zainteresovanim stranama tokom odgovora, ali se njihova uloga deljenja informacija o obimu događaja i preduzetim akcijama i merama, nastavlja ne samo tokom prvobitnog odgovora, već i kasnije, u fazi oporavka; 8. radio, mobilni uređaji, faks, televizija, telefonske linije za hitno reagovanje, meteorološki satelitski sistemi i drugi instrumenti telekomunikacione i komunikacione mreže: koriste se za brži i sigurniji protok informacija, prenos podataka radi poboljšanja situacione svesti i optimizacije korišćenja resursa, te pomoć pri koordinisanim akcijama odgovora i spasavanja.

Od svih navedenih, kako u pogledu dostupnosti, tako i brzine porasta broja korisnika, mobilne tehnologije se poslednjih godina najbrže šire. Dok su na samom početku razvoja one bile bazirane na mrežnim porukama i pozivima, uz ogroman rast u primeni mobilnih uređaja, razvile su se i sve sofisticiranije mobilne usluge (Hassan \& Ayub, 2015). Trenutne aktivnosti iz oblasti sistema za upravljanje katastrofama uz pomoć mobilnih uređaja variraju od kratkih (SMS) poruka upozorenja (primer su Ujedinjeno Kraljevstvo i Hong Kong), pa sve do mogućnosti građana da uz pomoć mobilnih uređaja doniraju sredstva neposrednim putem ugroženim zemljama, kao što je to regulisano u Češkoj Republici 
(Souza \& Kushchu, 2005:456). S obzirom na važnost i obim, u sledećem poglavlju bavićemo se ne samo trendovima, nego i konkretnim primerima upotrebe mobilnih uređaja u katastrofama, kao i nezaobilaznim propratnim izazovima.

\section{Upotreba mobilnih komunikacionih sistema (telefona) u periodima pre, za vreme i nakon katastrofa}

Inovativna rešenja u pogledu načina korišćenja mobilnih tehnologija bila su u direktnoj sprezi sa unapređivanjem taktičkih i tehničkih metoda upravljanja u uslovima katastrofa. Uopšteno uzev, mobilni telefoni omogućavaju vitalnu podršku menadžmentu kroz različite mogućnosti podrške u monitoringu, komunikaciji, širenju upozorenja, pružanju informacija o evakuaciji, spasavanju i slično (Soni et al., 2014:9). Distribuirati odgovarajuću informaciju u blagovremenom trenutku jeste krucijalan i istovremeno izuzetno zahtevan korak neophodan za sprečavanje nastanka štete i gubitka ljudskih života, odnosno adekvatnog reagovanja onda kada se određena opasnost već dogodi, ali i pružanja pomoći u procesu rehabilitacije. Jedna od osnovnih karakteristika katastrofa jeste da uništavaju kritičnu komunikacionu infrastrukturu i na taj način onemogućavaju funkcionisanje mobilne telefonije. Iz tih razloga, a imajući u vidu da je efikasnost odgovora, oporavka i rehabilitacije nastradalih društvenih zajednica u direktnoj vezi sa uspešnim funkcionisanjem sistema, potrebno je ojačati ove sisteme veza. Mobilni uređaji su izuzetno pogodni za komunikaciju i upravljanje katastrofama, a karakteristike koje in čine takvima su sledeće (Sweta, 2014:357): zbog svojih malih dimenzija, proporcionalno je uvećana moć prenosa i tako se mogu upotrebljavati bez ikakvih težinskih opterećenja po korisnika; mobilni uređaji se mogu napuniti i koristiti više sati ili dana na terenu na kom ne postoji mogućnost električnog snabdevanja; multifunkcionalnost mobilnih uređaja omogućava primanje višestrukih i različitih tipova informacija, kao što su poruke, imejlovi, podaci i pozivi od drugih udaljenih korisnika; modifikovane web aplikacije za mobilne platforme pružaju šansu korisnicima da dođu do potrebnih informacija bez nepotrebnog pokretanja internet pregledača. Tačna i pravovremena informacija koja se može dobiti i pružiti putem mobilnih uređaja korisna je u svim fazama upravljanja katastrofama, naročito u fazi pripreme odnosno upozorenja o nadolazećoj opasnosti i prvobitnom odgovoru. U realnosti, mobilne komunikacione sisteme koriste svi za različite privatne, poslovne i zabavne aktivnosti. Često, događa se da građani koji primete određenu opasnost mogu preko mobilnog telefona obavestiti nadležne organe i time uveliko doprineti njihovoj efikasnijoj reakciji.

Upozorenja o nadolazećim opasnostima putem izgrađenih sistema za rano upozoravanje i obaveštavanje su efikasna kada je reč o predvidljivim opasnostima poput poplava, uragana ili tornada, tada mrežni operater direktno šalje SMS stanovnicima ugroženog područja kako bi se pravovremeno pripremili za moguću evakuaciju (Soni et al., 2014:9). U situacijama kada je teško uočiti kada će se opasnost razviti i kada ne postoji nikakvo upozorenje, posledice katastrofe mogu biti iznimno tragične i materijalno obimne. Upravo u ovim okolnostima, zajednica može imati koristi od mobilnih uređaja i njihovih korisnika koji su neposredno ugroženi ili pogođeni katastrofom, tako što će se oni služiti mobilnim telefonima kao instrumentima za rano upozoravanje prosleđujući informacije koje poseduju dalje svojim komšijama, prijateljima, nadležnim službama i drugima, bilo direktno pozivom, porukom, ili indirektno postavljanjem statusa i izveštaja 
na socijalne mreže i web (Sweta, 2014:357). Većina operacija tokom katastrofa koordinira se iz operativnog centra za katastrofe, koji je obično smešten na određenoj fizičkoj lokaciji. Zbog pritisaka na donosioce odluke da omoguće javnu dostupnost informacija o trenutnoj situaciji u realnom vremenu, došlo je do promene trenda (Botterell \& Griss, 2011), te se informacije više ne čuvaju u određenim centrima i samo za nekolicinu privilegovanih, a ovakva promena je usledila sa razvojem „web-a 2.0“, „WiFi“, mobilnih tehnologija, posebno u kontekstu evolucije primene socijalnih mreža, te različitih mobilnih aplikacija. Informacije sakupljene mobilnim uređajima od strane volontera (Cvetković, Milašinović, \& Lazić, 2018), medija ili samih ugroženih iz zone opasnosti, bilo da su u pitanju audio, video zapisi ili fotografije mogu se „geotagovati i geokodirati”, što otvara prostor za niz novih mogućnosti iskorišćavanja tih informacija tokom katastrofa (Roche, Propeck-Zimmermann \& Mericskay, 2013). Tako bi zahvaljujući geokodiranim delovima informacije, bilo mnogo lakše praviti planove i donositi odluke o npr. spasilačkim operacijama. Pripadnici interventno-spasilačkih službi bili bi u mogućnosti da u svakom trenutku i u što kraćem vremenskom periodu identifikuju tačnu poziciju ugroženih ljudi što bi uveliko pospešilo njihov efikasniji odgovor. Upotreba mobilnih telefona u poboljšanju odgovora na katastrofu evidentna je i kroz praćenje odašiljanog signala sa uređaja njihovih korisnika među stanovništvom na ugroženom području. Pozicija korisnika se može utvrditi ili preko telefonskih prijemnika, proksi servera ili globalnog sistema za pozicioniranje, ako je on uključen (Gething\& Tatem, 2011:1).

Otvorenim protokom komunikacija putem mobilnih uređaja promoviše se uključivanje opšte javnosti i drugih privatnih entiteta, koji takođe poseduju informacije od značaja za delovanje u svim fazama katastrofa. Dosadašnja komunikaciona mreža tokom katastrofa pokazala se nedovoljno efikasnom i birokratskom, stoga Sveta (Sweta, 2014) predlaže da se putem bežične komunikacione strukture i glavnog komandnog centra omogući i neposredan slobodan tok informacija na liniji od centralne vlasti do povezanih agencija i službi, poput policije, vatrogasno-spasilačkih timova, ali i dalje do preživelih i pogođenih katastrofom koji će potvrditi postojeće informacije i interaktivno istovremeno sa službama zaduženim za odgovor učestvovati u procesu odgovora i oporavka. S obzirom da je koordinacija informacija nemoguća bez slobodnog konstantnog protoka relevantnih informacija (Meissner et al., 2002), uz pomoć ovakve platforme, menadžeri srednjeg i najvišeg nivoa koji nisu prisutni na terenu, a rukovode aktivnostima, kao i timovi odgovorni za neposrednu pomoć, preplavljeni su direktnim informacijama poput mogućih pristupnih puteva do pogođene lokacije, ili potencijalnim gubicima, a primarna briga u upravljanju katastrofama koja se odnosi na kriznu komunikaciju i deljenje pouzdanih informacija i širem okruženju, bila bi ako ne rešena, onda sigurno manja (Comfort, 2007). Tako se upotrebom mobilnih komunikacija promovišu javna svest i kolaboracija kao temeljni stubovi timskog rada u upravljanju katastrofama.

\section{Uloga pametnih telefona u procesu upravljanja katastrofama}

Jedan od najvećih izazova u savremenom upravljanju katastrofama odnosi se na razvijanje mogućnosti i ostvarivanje preduslova da se u kratkom vremenskom periodu identifikuju i opišu najznačajnije karakteristike manifestovane katastrofe, ali i da se što pre obavesti javnost u fazama pre, za vreme i nakon ispoljavanja posledica katastrofa. U praksi, nije neuobičajeno da se pripadnici interventno-spasilačkih jedinica žale da im nedostaju „prave in- 
formacije, u pravo vreme". Svako odlaganje dobijanja spomenutih informacija, automatski znači i kašnjenje u procesu pružanja pomoći što direktno prouzrokuje rast posledica. U današnje vreme, zahvaljujući automatskim i inteligentnim sistemima, život je znatno olakšan, a to se pogotovo odnosi na periode vanrednih situacija. Tako su pametni telefoni primer tehnologije koja ima niz benefitnih funkcija za njihove korisnike i celokupnu zajednicu u periodu pre, za vreme i posle katastrofa. Upotreba pametnih telefona u upravljanju katastrofama znatno je, putem globalnog sistema za pozicioniranje (GPS), unapredila praćenje ugroženih, zaposlenih iz vladinih i nevladinih organizacija, volontera i svih ostalih aktivnih aktera. Ove mogućnosti ostvaruju se na dva načina, ili pomoću mobilnog mrežnog signala gde će u ovom slučaju signali odašiljani u bazu biti pokazatelj lokacije (Chowdhury, Mridul \& Kushchu, 2005:245), ili pomoću platformi za izračunavanje pozicije sa ugrađenim senzorima poput onih koji detektuju lokaciju korisnika na mapi, u zavisnosti od jačine geomagnetskog polja (Maryam et al., 2016:301). Takođe, korisnici pametnih telefona imaju prilike da šalju i primaju ažurirane informacije o trenutnoj katastrofi ne samo putem bežične komunikacije, pri čemu se koriste protokoli velikog dometa, već i putem bežične senzorske mreže, koju karakterišu protokoli kratkog dometa (Miluzzo et al., 2008). Prilikom korišćenja različitih aplikacija, koriste se i različiti senzori ugrađeni u pametne telefone poput akcelerometra, magnometra itd. (Chowdhury, Mridul \& Kushchu, 2005).

$\mathrm{U}$ periodu pre ali i u trenutku ispoljavanja štetnih dejstava katastrofa, potrebno je obavestiti sve građane o ispoljenim ali i predstojećim opasnostima. Ukoliko su takve osobe svesne i budne, pokušaće da se detaljnije informišu i po potrebi evakuišu, a u drugom slučaju, trebalo bi da postoje mehanizmi koji će automatski detektovati opasnost i upozorenjem naglasiti bitnost i hitnost situacije. Pravovremena akcija i reakcija u takvim slučajevima predstavlja veliki izazov (Maryam et al., 2016:302) i istovremeno priliku da pametni telefoni olakšaju suočavanje s njim. Glavni ciljevi korišćenja pametnih telefona u procesu upravljanja u katastrofama ogledaju se u automatskom otkrivanju bilo koje vrste opasnosti korišćenjem ugrađenih senzora koji će omogućiti izbor adekvatnog načina reagovanja u datoj situaciji. Pored toga, omogućavaju podršku za razmenu tačnih podataka, kao i automatsko obaveštavanje ili upozoravanje o toku događaja svih zainteresovanih strana putem notifikacija, imejlova, SMS-a itd. Na kraju, olakšavaju odgovore na nastale katastrofe uz minimalne intervencije i napore ljudskih i materijalnih kapaciteta. Značajno je spomenuti da se efikasnost korišćenja mobilnih telefona u procesu upravljanja u uslovima katastrofa najbolje da ilustrovati na primerima ,,3D vizualizacije“ i „Crowdsensing-a” (Maryam et al., 2016:303). Modernim trendovima u primeni pametnih telefona u ovoj oblasti, dominira stanovište da se stalno radi na kontroli kvaliteta, te da nema suvišnih podataka. Trodimenzionalne GIS baze podataka sadrže 3D strukture podataka koje reprezentuju istovremeno i geometriju i topologiju 3D oblika (Kalkofen, Mende \& Schmalstieg, 2007). Kako bi vizualizacija, koja može olakšati mnogo operacija, bila moguća koriste se podaci nastali praćenjem mobilnih uređaja. Mobilni uređaji su značajni instrumenti tokom odgovora na katastrofu tako što efikasno mogu da vizuelizuju relevantne, selektovane informacije (na primer fotografije, 3D modele, podatke koje sakupljaju senzori) i predstave potencijalna rešenja situacije.

Kim i saradnici (Kim et al., 2007) su razvili vizuelni analitički sistem za mobilne telefone koji procesuira podatke prikupljene senzorima i lokaciju, a zatim ih na jednostavan, lako čitljiv način prikazuje, što zaposlenima omogućava efikasniji odgovor i planiranje operacija. U cilju smanjivanja stope rizika po gubitak ljudskih života i povećanje brzine i bez- 
bednosti evakuacije, zaposleni u spasilačkim službama mogu koristiti pametne telefone pri prikazu digitalnih planova zgrada, a u kojima instaliran akcelerometar može identifikovati organizaciju ili objekat na kom se lice nalazi (Maryam et al. , 2016:304).

Progresivnim napretkom industrijskih tehnologija, kao i povećanjem broja pametnih telefona, ljudi su zakoračili u eru Interneta stvari „Internet of Things (IoT)“, koja povezuje različite fizičke objekte i njihova okruženja na realističniji i sveobuhvatniji način (Ma, Zhao \& Yuan, 2014:29). Način prikupljanja podataka, ideja, usluga poznat kao „crowdsensing“ putem uređaja i senzora nam može obezbediti upravo takve detaljne i realne informacije o trenutnoj situaciji pre, tokom i nakon katastrofe. Postoji niz eksperimentalnih projekata koji istražuju sveprisutnost senzora u pametnim telefonima, a pomoću kojih možemo dobiti kritične informacije o infrastrukturnim oštećenjima, podrhtavanjima, ili požarima tokom zemljotresa. Akcelerometri ugrađeni u današnje pametne telefone se mogu koristiti kako bi se brzo i jeftino izmerila jačina podrhtavanja i to sa mnogo većom prostornom rezolucijom nego što je to moguće uz pomoć profesionalnih visokokvalitetnih senzora kao što je K-NET u Japanu. Takvo praćenje jačine potresa može biti izuzetno korisno za analizu kumulativnog uticaja podrhtavanja na građevine, a pogotovo za dizajniranje bezbednijih fizičkih konstrukcija (Konomi et al., 2015: 449).

Požari, često izazvani zemljotresima, mogu prouzrokovati značajnu štetu stanovnicima. Rana identifikacija lokacije požara bitna je kako bi se predvidelo širenje požara i napravio adekvatan evakuacioni plan. Relativno su retka istraživanja detekcije požara pametnim telefonima, međutim, ista grupa naučnika sa dva japanska univerziteta (Konomi et al., 2015: 449 ) ispitivali su kako se pametni telefoni poslednje linije poput SAMSUNG Galaxy 4, opremljenih temperaturnim i senzorima vlažnosti vazduha, mogu upotrebiti kako bi se odredila verovatnoća nastanka požara, ako se dostigne određena visoka temperatura i niska vlažnost. Piter i saradnici (Haddawy et al., 2015) prezentovali su kako 4D pametni telefoni mogu pomoći pri uzbunjivanju i širenju informacija od kritične važnosti. U slučaju nadolazeće opasnosti, bilo da je reč o poplavama, požarima, epidemijama, kada administrator pošalje upozorenje, korisnici 4D mobilnog uređaja u zavisnosti od svoje lokacije, putem aplikacija i „,crowdsource" sistema, istovremeno ne samo da u realnom vremenu primaju to upozorenje, obaveštavaju se o potencijalnim alternativnim pravcima razvoja događaja, nego i dopunjene informacije sa lica mesta šalju dalje, te se tako razvija platforma koja omogućava podizanje svesti stanovništva o uslovima koji ih okružuju i brzo reagovanje u vanrednim situacijama.

\section{Uloga mobilnih aplikacija u pružanju pomoći ugroženim ljudima u katastrofama}

U toku 2009. godine, Fajardo i Opus (Fajardo \& Oppus, 2009) razvili su aplikaciju „,My Disaster Droid (MDD)" koja izračunava najbolje rute za stizanje na različite geografske lokacije. Tako izračunate rute pomažu volonterima i pripadnicima interventno-spasilačkih službi da dođu do maksimalnog broja ugroženih ljudi za najbrže moguće vreme. Aplikacija funkcioniše tako što su geografske lokacije opisane geografskom širinom i dužinom, a prikazuju se u vidu „,MapView“i , ListView“. MapView koristi „Google Maps“ kako bi prikazao lokaciju na mapi, dok „,ListView“ prikazuje informacije o ljudima kojima je potrebna pomoć, njihovim lokacijama i distanci od lokacije korisnika izražene u kilometrima (Fajardo \& Oppus, 2010). Pored spomenute aplikacije, razvijena je i „Smart Rescue“ koja omogućava da 
se identifikuju i obeleže sve potencijalne pretnje i mogući saveti za njihovo savladavanje. Pored toga, automatski se prosleđuju pozivi za pružanje pomoći. Spomenuta aplikacija može poslužiti istovremeno i kao instrument komunikacije u katastrofama s obzirom da je njeni korisnici mogu upotrebiti u svrhu širenja upozorenja o bilo kojoj vrsti opasnosti na određenoj lokaciji. Može izvoditi komplikovane zadatke bez brzog trošenja baterije i uticaja na normalno funkcionisanje pametnog telefona (Maryam, 2016:304).

U cilju davanja korisnicima određene preliminarne instrukcije kako da pruže prvu pomoć u zavisnosti od povrede, te da im prikaže najbrži, najprohodniji pravac do najbliže bolnice, razvijena je aplikacija za pružanje prve medicinske pomoći. U slučaju bilo katastrofe, aplikacija se pokazala kao odlično sredstvo koje pruža upravo dve vrste usluga: prva, odnosi se na niz uputstava o pružanju medicinske pomoći; druga, pronalazak tačne, adekvatne i funkcionalne putanje do bolnice. Kada je reč o pružanju prve pomoći, dostupne su informacije o neophodnim medicinskim merama za ublažavanje povreda uzrokovanih povredama mišića i kože. Kod druge usluge, koristi se u mobilni telefon ugrađen globalni sistem za pozicioniranje, čime se omogućava ne samo pronalazak i izračunavanje najbliže bolnice, nego i mogućnost navigacije do željene, a pre toga korisnikovom odlukom birane lokacije (Maryam, 2016:304).

U cilju ublažavanja posledica zemljotresa, razvijena je aplikacija „Quake SOS“ koja predstavlja svojevrsnu aplikaciju osmišljenu i dizajniranu za rano upozoravanje i brzo pozivanje pomoći. Omogućava korisniku da se u slučaju nastanka opasnosti, odnosno zemljotresa, informiše da li je na bezbednom ili mu je potrebna pomoć. Takođe, aplikacija sadrži bazu podataka o svim prethodnim zemljotresima sa detaljima gde i kada su se dešavali i takva baza se periodično ažurira nakon instalacije na pametnom telefonu (Maryam et al., 2016:304). Federalna agencija za upravljanje vanrednim situacijama (FEMA) Sjedinjenih Američkih Država razvila je aplikaciju za podizanje svesti o različitim vrstama opasnosti. Aplikacija se primarno koristi da bi se stanovništvo bolje pripremilo pre nastanka katastrofe, ali se ona može upotrebljavati i nakon njenog nastanka s obzirom da sadrži npr. interaktivnu ček-listu neophodne opreme za preživljavanje takvih događaja; mogućnost podsetnika u vidu lekcija kako ostati bezbedan pre, za vreme i nakon katastrofa izazvanih različitim izvorima opasnosti uključujući poplave, uragane, tornada i zemljotrese; zatim omogućava dobijanje upozorenja od Nacionalne službe za vremensku prognozu u slučaju predviđanja nastanka opasnosti; deljenje fotografije iz zone ugroženosti tokom katastrofa, koje se kasnije uz pomoć socijalnih medija prosleđuju i služe daljem obaveštavanju stanovništva o opasnostima, ali i pomaže pripadnicima spasilačkih službi da brzo reaguju (FEMA). Pored toga, postoji i besplatno dostupna mobilna aplikacija ,Disaster Alert“ koja omogućava praćenje višestrukih opasnosti širom sveta, dobijanje izveštaja o njima, kao i mogućnost njihovog deljenja na društvenim mrežama, ali i rano upozoravanje za aktivne opasnosti (Pacific Disaster Center).

\section{Izazovi i ograničenja upotrebe mobilnih telefona u katastrofama}

Primarni izazov u odgovoru na svaku prirodnu ili tehničko-tehnološku opasnost jeste komunikacija, i prožima se mnogo dalje od pitanja povezanih isključivo sa interoperabilnošću. Na osnovu praktičnih posmatranja vežbi i treninga spasilačkih službi, radnih diskusija i ispitivanja koje su sproveli, Manođ i Beker (Manoj \& Baker, 2007) su identifikovali 3 glavne kategorije ko- 
munikacionih izazova povezanih sa informaciono-komunikacionim tehnologijama i mobilnim telefonima u katastrofama, a to su: tehnološki, sociološki i organizacioni. Jedan od glavnih tehnoloških izazova nakon manifestacije katastrofe jeste razvoj i održavanje informaciono-komunikacionog sistema za sve subjekte i snage zaštite i spasavanja, volontere i građane. Irelevantno je da li su informaciono-komunikacione mreže u potpunosti uništene, ili one uopšte i ne postoje, ako su u pitanju zabačene geografske površine. U takvim okolnostima, razvoj novih sistema može biti još komplikovanije s obzirom na komunikacionu infrastrukturu koja delimično ili apsolutno ne funkcioniše, što može dovesti do zavisnosti od ljudi kao glavnih aktera komunikacionog sistema. Druga bitna prepreka koju je potrebno prevazići jesu pitanja vezana za višeorganizacijsku interoperabilnost. Kako bi se u budućnosti takvi sistemi u katastrofama srednjeg i velikog obima učinili produktivnijim, potrebno je u njihov dizajn inkorporirati dva tehnološka rešenja, dvostruku upotrebu tehnologija koja bi podrazumevala rad u normalnom i vanrednom režimu, kao i smanjivanje izlišnosti, koja bi se prevazišla korišćenjem uređaja sa višestrukim mrežnim sposobnostima (kao što su pametni telefoni sa „WLAN“ ili ,,bluetooth“ interfejsom). Ako se bazične stanice unište, mobilni uređaji mogu formirati lokalnu mrežu.

Socijalni izazovi koji se javljaju tokom komunikacije u uslovima katastrofa između grupa na različite načine, nameću neophodnost razumevanja modela ljudskih aktivnosti i ponašanja tokom ovih događaja, posebno onih koji se odnose na dostupnost, pristupačnost i primenjivost informacionog rešenja (Manoj \& Baker, 2007). Deljenje i proliferacija informacija je istovremeno, i od kritične važnosti, i problematična, počevši od toga kome verovati u novouspostavljenom i nesigurnom okruženju. Čak i kada se dostigne određeni nivo poverenja, i dalje su aktuelna pitanja bezbednosti. Bitan faktor je takođe i emotivna i psihička promenjivost stanja ugroženih i žrtava katastrofa, a stres, strah i druge emocije otežavaju prisebnost i intenziviraju se sa nedostatkom informacija. Takav problem se parcijalno rešio s pojavom i primenom prethodno pomenutih mobilnih aplikacija, međutim i tu postoji ogroman prostor za napredak, kako u smislu efikasnosti tako i nedovoljne volje i edukacije stanovništva da iste koriste. Katastrofe su često visokopolitizovane situacije u kojima je izveštavanje i dostupnost informacija strogo ograničena ili zabranjena u zavisnosti od prirode opasnosti, a posebno kada ne postoji kooperacija među akterima koji u njima učestvuju. Upravo mobilne tehnologije mogu obezbediti da se prevaziđe ovaj problem, i omoguće otvorenu i što slobodniju i neposredniju komunikaciju među (ne)vladinim sektorom i građanima, čak i u slučaju kada su oštećeni ili uništeni glavni komunikacioni prijemnici ili preopterećeni tradicionalni izvori obaveštavanja kao što su SMS poruke i pozivi. Međutim, izveštavanje u realnom vremenu može prouzrokovati drugi problem koji se ogleda u preopterećenosti velikim brojem informacija kojima nedostaje koordinacija i uspešno upravljanje (Sweta, 2014:358), što nas dovodi do poslednje kategorije izazova, kako toliki broj informacija, većinom neproverenih, organizovati.

Organizacioni izazovi preovlađuju naročito u fazi odgovora, kada postoji preopterećenost informacijama, ali i veliki potencijal za njihovu irelevantnost, te tako vode do haosa i pomešanih reakcija tokom samog upravljanja u uslovima katastrofa (Sweta, 2014:359). $\mathrm{Na}$ to treba dodati, neophodnost prisutnosti konstantnih interaktivnih povratnih informacija radnika, volontera ali i građana iz zone ugroženih, kao i rukovodioca i menadžera iz operativnih centara, kako bi se činjenice o situaciji osvežavale u realnom vremenu, a sa druge strane, posebno kada grupe u normalnim okolnostima naviknute na hijerarhiju i centralizovano donošenje odluka, odjednom moraju da rade u dinamičnom, privremenom okruženju, teško je usaglasiti ova dva pristupa - nužnost informacija, njihov preveliki 
broj, potrebu da one budu što preciznije, konciznije, ali i da se pravovremeno razmenjuju između svih uključenih aktera. Međutim, kako je već pomenuto, kolaborativne tehnologije poput mobilnih, i istaknutih aplikacija, mogu pomoći u poboljšanju međuorganizacione komunikacije (Farnham, Pedersen \& Kirkpatrick, 2006). Dakle, mobilni uređaji i aplikacije razvijene na nacionalnom i međunarodnom nivou učinile su katastrofe od lokalnih, globalnim fenomenima. Međutim još uvek postoje delovi sveta i strukture stanovništva koje sebi, ili ne mogu da priušte pametne telefone ili nisu upoznati sa ovakvim mogućnostima, te nisu razvili potrebne veštine kako bi sa jedne strane, kao volonteri ili građani adekvatnije pomogli ugroženima, a sa druge strane, nadležne službe i nevladine organizacije brže, kvalitetnije i kompetentnije obavljali poslove upravljanja u katastrofama.

\section{Upotreba mobilnih podataka pri odgovoru na katastrofu: studija slučaja Haitija}

Upravljanje katastrofama zahteva tačne informacije i povezivanje sakupljenih podataka sa analizom kako bi se proces donošenja odluka učinio produktivnijim. Postojeći pristupi pružanju pomoći odmah nakon tragičnog događaja, poput dugoročnog premišljanja u štabovima za vanredne situacije o najboljim transportnim ili evakuacionim putevima, kao i ručna registracija po sistemu „papira i olovke” žrtava na stanicama za prihvat i zbrinjavanje, često su neadekvatni i sve više zastareli. U praksi, najdostupniji izvori informacija jesu „živi svedoci” ili medijski izveštaji. lako mogu biti pravovremeni, ovakvi izveštaji ne sakupljaju se sistematično i mogu produkovati pristrasno predstavljanje događaja. Međutim sa razvojem mobilne tehnologije i svesti ljudi, došlo je i do revolucionarnih promena u praćenju kretanja ugroženih pomoću prikupljenih mobilnih podataka.

Lokacija korisnika mobilnih telefona sa kojih se šalju pozivi ili tekstualne poruke određuje se pomoću najbližeg mrežnog prijemnika. Sve do 2011. godine potencijal za praćenje žrtava putem mobilnih podataka u haotičnom okruženju neposredno nakon katastrofa nije bio dovoljno istražen. Bengtson i saradnici (Bengtsson, Lu, Thorson, Garfield \& Von Schreeb, 2011) su u toku 2011. godine prezentovali analizu procene broja i putanje kretanja raseljenih lica nakon razornog zemljotresa na Haitiju 12. januara 2010. godine, a na osnovu mobilnih podataka. Oni su retrospektivno došli do sakupljenih podataka za period od 6 nedelja pre, do 5 meseci nakon katastrofe, uključujući analizu 282 miliona poziva sa 2.8 miliona pojedinačnih mobilnih uređaja. Nakon postavljenih jednostavnih pretpostavki, istražili su broj raseljenih lica, vremenski period u kom i za koji su se kretali, te lokacije do kojih su putovali. Njihova studija pokazale je da je njihova procena bila mnogo približnija detaljnim rezultatima na drugi način sprovedenih istraživanja, čime se sugeriše da mobilni podaci omogućavaju mnogo detaljniju i precizniju sliku kretanja populacije za mnogo kraće vreme od onih koji se standardno koriste u toku odgovora. Krucijalno pitanje je da li se pristup koji su predstavili Bengtson i saradnici može operacionalizovati, sa podacima koji će biti sakupljeni, analizirani i dostavljeni u realnom vremenu tokom katastrofe licima koji upravljaju akcijama odgovora. Autori su odgovorili i na ovo pitanje tako što su primenili svoj pristup u realnom vremenu prativši kretanje pojedinaca nakon izbijanja epidemije kolere posle zemljotresa. Uspeli su da primene svoju analizu i objave rezultate u roku od 12 sati nakon što su dobili pristup mrežnim podacima. 
Potencijalne prednosti upotrebe mobilnih podataka za praćenje populacije su očigledne: podaci su pravovremeni, obilni i nije potreban napor za njihovo prikupljanje. Ipak, određena ograničenja takođe moramo imati u vidu (Gething \& Tatem, 2011:2). Prvo, katastrofe mogu uništiti mrežu, ograničavajući pokrivenost, dostupnost i upotrebu mobilnih podataka, dok nestanak struje može prouzrokovati nemogućnost dopunjavanja baterije mobilnih uređaja. Takođe, prekogranično raseljavanje stanovništva je poseban izazov za praćenje, s obzirom na mrežnu pokrivenost nacionalnih operatera samo svoje teritorije. Treće ograničenje odnosi se na reprezentativnost uzorka populacije na osnovu kojih se izvode analize, s obzirom da mnoge strukture društva još uvek u velikom broju zemalja ne poseduju mobilne telefone, posebno se to odnosi na ruralno stanovništvo, žene, siromašne i stare. I poslednji izazov tiče se bezbednosti preuzetih podataka, tako da bi se morali razviti protokoli koji će osigurati privatnost korisnika.

\section{Zaključak}

Budućnost u kojoj će informaciono-komunikacione tehnologije doživeti svoju ekspanziju, doneće sa sobom određene pogodnosti i inovacije, koje će omogućiti donosiocima odluka da vrlo brzo, racionalno i na bazi svih relevantnih informacija izaberu odgovarajuće i najefikasnije rešenje u pogledu ublažavanja, odgovora i oporavka od posledica katastrofa. Imati pravu informaciju u pravo vreme od kritične je važnosti u svim fazama upravljanja katastrofama, bilo da se radi o pripremi, odgovoru ili oporavku i rehabilitaciji ugroženog područja i zajednice. Značajno uvećan broj korisnika mobilnih telefona, koji koriste 3G i 4G, kao i socijalnih mreža, doveo je i do poboljšanja kanala ne samo svakidašnjih, već i kriznih komunikacija. Sa ekspanzijom protoka 3G i Wifi mreža širom sveta, te razvojem Android i drugih operativnih sistema, ušli smo u novu eru u kojem dominiraju i novi žanrovi geotagovanih i geokodiranih informacija koje dodaju vrednost prethodnim funkcijama i upotrebi mobilnih uređaja pre, za vreme i nakon katastrofa, jer se korisnici, između ostalog, javljaju i kao mikro blogeri u identifikaciji opasnosti, ugroženih i preživelih, njihovih lokacija, te deljenju tih informacijama dalje putem mreže.

S obzirom da smo u radu istakli svojstva mobilnih telefona koja ih čine pogodnim za pomoć različitim službama, organizacijama, ali i samim građanima i ugroženima pri delovanju u katastrofama, te niz mobilnih aplikacija putem kojih je to znatno olakšano, treba istaći važnost podizanja svesti o prednostima njihove upotrebe, edukovati stanovništvo kako ih koristiti, te podstaći dalja istraživanja iz ove oblasti. Svako, a posebno osobe koje žive na teritoriji ugroženoj nizom rizika, bi trebao da instalira aplikacije koje im mogu pomoći u vanrednim situacijama, jer se često zaboravlja da u takvim okolnostima, upravo one mogu spasiti život njih samih, ali i drugih ljudi. Sa druge strane, treba ohrabriti programere za razvoj novih mobilnih aplikacija, te što proaktivnije iskorištavanje postojećih mogućnosti upotrebe i karakteristika mobilnih telefona za izbegavanje i ublažavanje posledica od katastrofa. Samo sveobuhvatna i sistematična borba sa izazovima i ograničenjima koje informaciono-komunikacione i mobilne tehnologije sa sobom nose, prilagođavanje i delovanje u toku sa tehnologijama, može zaista unaprediti ne samo kriznu komunikaciju, interoperabilnost, i druge pojedinačne segmente, nego i čitav proces upravljanja katastrofama. 


\section{Literatura}

[1] Aleksandrina, M., Budiarti, D., Yu, Z., Pasha, F., \& Shaw, R. (2019). Governmental incentivization for SMEs' engagement in disaster resilience in Southeast Asia. International Journal of Disaster Risk Management, 1(1), 32-50.

[2] Bengtsson, L., Lu, X., Thorson, A., Garfield, R., \& Von Schreeb, J. (2011). Improved response to disasters and outbreaks by tracking population movements with mobile phone network data: a post-earthquake geospatial study in Haiti. PLoS medicine, 8(8), e1001083.

[3] Botterell, A., \& Griss, M. (2011). Toward the next generation of emergency operations systems. Proceedings of the 8th International ISCRAM Conference (Lisbon, Portugal, May 2011).

[4] Carter, W. N. (2008). Disaster management: A disaster manager's handbook. Mandaluyong City, Philippines: Asian Development Bank.

[5] Chowdhury G., Mridul H., \&. Kushchu. (2005). Prospects of using m-technologies for disaster information management in Bangladesh and other LDCs. EURO mGOV, Brighton, UK, 243-253.

[6] Comfort, L. K. (2007). Crisis management in hindsight: Cognition, communication, coordination, and control. Public Administration Review, 67(s1), 189-197.

[7] Cvetkovic, V. M. (2019). Risk perception of building fires in Belgrade. International Journal of Disaster Risk Management, 1(1), 81-91.

[8] Cvetković, V. M., Öcal, A., \& Ivanov, A. (2019). Young adults' fear of disasters: A case study of residents from Turkey, Serbia and Macedonia. International Journal of Disaster Risk Reduction, 101095. doi: https://doi.org/10.1016/j.ijdrr.2019.101095

[9] Cvetković, V., Giulia, R., Ocal, A., Filipović, M., Janković, B., \& Eric, N. (2018). Childrens and youths' knowledge on forest fires: Discrepancies between basic perceptions and reality. Vojno delo, 70(1), 171-185.

[10] Cvetković, V., Milašinović, S., \& Lazić, Ž. (2018). Examination of citizens' attitudes towards providign support to vulnerable people and voluntereeing during disasters. TEME, 42(1), 35-56.

[11] Cvetković, V., Noji, E., Filipović, M., Marija, M. P., Želimir, K., \& Nenad, R. (2018a). Public risk perspectives regarding the threat of terrorism in Belgrade: Implications for risk management decision-making for individuals, communities and public authorities. Journal of Criminal Investigation and Criminology, 69(4), 279-298.

[12] Cvetković, V., Roder, G., Öcal, A., Tarolli, P., \& Dragićević, S. (2018). The role of gender in preparedness and response behaviors towards flood risk in Serbia. International Journal of Environmental Research and Public Health, 15(12), 2761. doi: https://doi.org/10.3390/ijerph15122761

[13] Deshmukh, R., Rodrigues, L. L. R., \& Krishnamurthy, G. R. (2008). Earthquake risk and knowledge management. Journal of Knowledge Management Practice, 9(3).

[14] Fajardo, J. T. B., \& Oppus, C. M. (2010). A mobile disaster management system using the android technology. WSEAS Transactions on Communications, 9(6), 343-353.

[15] Farnham, S., Pedersen, E., \& Kirkpatrick, R. (2006, May). Observation of Katrina/Rita Groove deployment: Addressing social and communication challenges of ephemeral groups. Proceedings of the 3rd International ISCRAM Conference (39-49).

[16] Fatma, N. G. (2012). Sustainability and using information technologies in disaster managament. Nazilli, Aydın, Turkey: Faculty of Economic and Administritive Sciences.

[17] Federal Emergency Management Agency [FEMA]. https://www.fema.gov/mobile-app (4.5.2018.)

[18] Gething, P. W., \& Tatem, A. J. (2011). Can mobile phone data improve emergency response to natural disasters?. PLoS medicine, 8(8), e1001085. 
[19] Haddawy, P., Frommberger, L., Kauppinen, T., De Felice, G., Charkratpahu, P., Saengpao, S., \& Kanchanakitsakul, P. (2015, May). Situation awareness in crowdsensing for disease surveillance in crisis situations. Proceedings of the Seventh International Conference on Information and Communication Technologies and Development (38). ACM.

[20] Hassan, M., \& Ayub, A. (2015). Role of ICT in natural disaster management of Bangladesh (Doctoral dissertation, BRAC University). Dhaka, Bangladesh.

[21] International Federation of Red Cross and Red Crescent Societies [IFRC] (2012). World disasters report 2012: Focus on forced migration and displacement. Geneva (CHE): International Federation of Red Cross and Red Crescent Societies.

[22] Kalkofen, D., Mendez, E., \& Schmalstieg, D. (2007, November). Interactive focus and context visualization for augmented reality. Proceedings of the 2007 6th IEEE and ACM International Symposium on Mixed and Augmented Reality (1-10). IEEE Computer Society.

[23] Kim, S. Y., Jang, Y., Mellema, A., Ebert, D. S., \& Collinss, T. (2007, October). Visual analytics on mobile devices for emergency response. In 2007 IEEE Symposium on Visual Analytics Science and Technology. VAST (35-42). IEEE.

[24] Konomi, S. I., Kostakos, V., Sezaki, K., \& Shibasaki, R. (2015). Crowd sensing for disaster response and preparedness. 情報処理学会第 77 回全国大会, 6 (03), 449-450.

[25] Kumiko, F., \& Shaw, R. (2019). Preparing international joint project: Use of Japanese flood hazard map in Bangladesh. International Journal of Disaster Risk Management, 1(1), 62-80.

[26] Ma, H., Zhao, D., \& Yuan, P. (2014). Opportunities in mobile crowd sensing. IEEE Communications Magazine, 52(8), 29-35.

[27] Manoj, B. S., \& Baker, A. H. (2007). Communication challenges in emergency response. Communications of the $A C M, 50(3), 51-53$.

[28] Maryam, H., Shah, M. A., Javaid, Q., \& Kamran, M. (2016). A survey on smartphones systems for emergency management (SPSEM). International Journal of Advanced Computer Science \& Applications, 7(6), 301-311.

[29] Meissner, A., Luckenbach, T., Risse, T., Kirste, T., \& Kirchner, H. (2002, June). Design challenges for an integrated disaster management communication and information system. $U$ The First IEEE Workshop on Disaster Recovery Networks (DIREN 2002) (Vol. 24).

[30] Miluzzo, E., Lane, N. D., Fodor, K., Peterson, R., Lu, H., Musolesi, M., ... \& Campbell, A. T. (2008, November). Sensing meets mobile social networks: the design, implementation and evaluation of the cenceme application. Proceedings of the 6th ACM conference on Embedded network sensor systems (337-350). ACM.

[31] Moe, T. L., Gehbauer, F., Sentz, S., \& Mueller, M. (2007). Balanced scorecard for natural disaster management projects. Disaster Prevention and Management, 16(5), 785-806. doi:10.1108/09653560710837073

[32] Ocal, A. (2019). Natural disasters in Turkey: Social and economic perspective. International Journal of Disaster Risk Management, 1(1), 51-61.

[33] Pacific Disaster Center. https://www.pdc.org/apps/ (4.5.2018.)

[34] Palmer, N., Kemp R., Kielmann T., \& Bal, H. (2012). Raven: Using smartphones for collaborative disaster data collection. Proceedings of the 9th International ISCRAM Conference (Vancouver, April 2012). The Netherlands: VU University Amsterdam.

[35] Roche, S., Propeck-Zimmermann, E., \& Mericskay, B. (2013). GeoWeb and crisis management: Issues and perspectives of volunteered geographic information. GeoJournal, 78(1), 21-40. 
[36] Soni, A., Sharma, A., Kumar, P., Verma, V., \& Sutar, S. (2014). Early disaster warning \& evacuation system on mobile phones using google street map. International Journal of Engineering \& Technical Research (IJETR ), 2(4), 9-11.

[37] Souza, F., \& Kushchu, I. (2005). Mobile disaster management system applications-current overview and future potential. Proceedings EURO mGOV, 455-466.

[38] Sweta, L. O. (2014). Early warning systems and disaster management using mobile crowdsourcing. International Journal of Science and Research, 3(4), 356-365.

[39] United Nations Asian and Pacific Training Centre for Information and Communication Technology for Development [UN-APCICT/ESCAP] (2016). Academy of ICT Essentials for Government Leaders, Module 9: ICT for Disaster Risk Management.

[40] Warfield, C. (2008). The disaster management cycle. Disaster mitigation and management.

[41] Warren, C. M. J. (2010). The facilities manager preparing for climate change. Facilities, 28(11/12), 502-513. doi:10.1108/02632771011066567

[42] Xuesong, G., \& Kapucu, N. (2019). Examining stakeholder participation in social stability risk assessment for mega projects using network analysis. International Journal of Disaster Risk Management, 1(1), 1-31.

[43] Yodmani, S., \& Hollister, D. (2001). Disasters and communication technology: Perspectives from Asia. U Presented at the Second Tampere Conference on Disaster Communications (May 2001). 